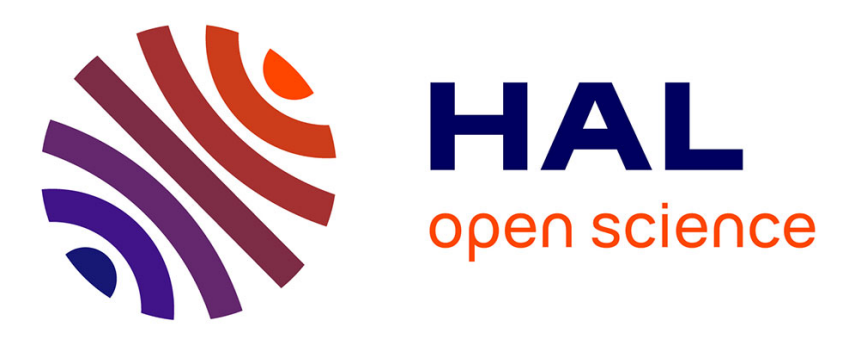

\title{
Mössbauer Spectroscopy Involved in the Study of the Catalytic Growth of Carbon Nanotubes
}

Pierre Coquay, Eddy de Grave, Robert E. Vandenberghe, Alain Peigney, Christophe Laurent

\section{- To cite this version:}

Pierre Coquay, Eddy de Grave, Robert E. Vandenberghe, Alain Peigney, Christophe Laurent. Mössbauer Spectroscopy Involved in the Study of the Catalytic Growth of Carbon Nanotubes. Hyperfine Interactions, 2002, vol. 139-140, pp. 289-296. 10.1023/A:1021239809363 . hal-00958261

\section{HAL Id: hal-00958261 https://hal.science/hal-00958261}

Submitted on 12 Mar 2014

HAL is a multi-disciplinary open access archive for the deposit and dissemination of scientific research documents, whether they are published or not. The documents may come from teaching and research institutions in France or abroad, or from public or private research centers.
L'archive ouverte pluridisciplinaire HAL, est destinée au dépôt et à la diffusion de documents scientifiques de niveau recherche, publiés ou non, émanant des établissements d'enseignement et de recherche français ou étrangers, des laboratoires publics ou privés. 


\section{OATAO \\ Open Archive Toulouse Archive Ouverte}

\section{Open Archive TOULOUSE Archive Ouverte (OATAO)}

OATAO is an open access repository that collects the work of Toulouse researchers and makes it freely available over the web where possible.

This is an author-deposited version published in : http://oatao.univ-toulouse.fr/ Eprints ID : 11138

To link to this article : DOI:10.1023/A:1021239809363

URL : http://dx.doi.org/10.1023/A:1021239809363

\section{To cite this version :}

Coquay, Pierre and De Grave, Eddy and Vandenberghe, Robert E. and Peigney, Alain and Laurent, Christophe Mössbauer Spectroscopy Involved in the Study of the Catalytic Growth of Carbon Nanotubes. (2002) Hyperfine interactions , vol. 139-140 $\left(\mathrm{n}^{\circ}\right.$ 1-4). pp. 289-296. ISSN 0304-3843

Any correspondance concerning this service should be sent to the repository administrator: staff-oatao@listes-diff.inp-toulouse.fr 


\title{
Mössbauer Spectroscopy Involved in the Study of the Catalytic Growth of Carbon Nanotubes
}

\author{
P. COQUAY ${ }^{1, *}$, E. DE GRAVE ${ }^{1}$, R. E. VANDENBERGHE ${ }^{1}$, A. PEIGNEY ${ }^{2}$ \\ and CH. LAURENT ${ }^{2}$ \\ ${ }^{1}$ NUMAT, Department of Subatomic and Radiation Physics, University of Gent, Proeftuinstraat 86, \\ B-9000 Gent, Belgium; e-mail: pierre.coquay@ rug.ac.be \\ ${ }^{2}$ CIRIMAT, UMR CNRS 5085/LCMIE, Centre Interuniversitaire de Recherche et d'Ingénierie \\ des Matériaux, Université Paul-Sabatier, 31062 Toulouse cedex 4, France
}

\begin{abstract}
Single-walled and thin multiwalled carbon nanotubes are prepared by a catalytic-chemicalvapor-deposition method involving the simultaneous formation of $\mathrm{Fe}$ or $\mathrm{Co}$ nanometric particles from oxide solid solutions based on $\mathrm{Al}_{2} \mathrm{O}_{3}, \mathrm{MgAl}_{2} \mathrm{O}_{4}$ or $\mathrm{MgO}$. This paper is an overview of the authors' work on the characterization by Mössbauer spectroscopy used in complement to electron microscopy and specific-surface-area measurements. It is notably attempted to correlate the nature of the different iron phases in the carbon nanotube-metal-oxide powders with the formation mechanisms of the nanotubes. Massive composites and hydrogen storage are proposed as possible applications.
\end{abstract}

Key words: carbon nanotubes, nanoparticles, CCVD, Mössbauer spectroscopy, applications.

\section{Introduction}

Since the report by Iijima [1] on carbon nanotubes (CNTs), many laboratories around the world have been studying this new form of carbon which presents high expectations for future applications such as light-weight composite materials, hydrogen storage and lithium-ion batteries.

The present authors have proposed an original catalytic-chemical-vapordeposition (CCVD) synthesis method in which single-walled and thin multiwalled carbon nanotubes (SWNTs and MWNTs, respectively) are prepared by reduction in a $\mathrm{H}_{2} / \mathrm{CH}_{4}$ atmosphere of oxide solid solutions based on $\mathrm{Al}_{2} \mathrm{O}_{3}$ [2], $\mathrm{MgAl}_{2} \mathrm{O}_{4}$ [3] or $\mathrm{MgO}$ [4]. Pristine metal (Fe, $\mathrm{Co}, \mathrm{Ni}$ and their alloys) nanoparticles are formed upon reduction of the solid solution, at a relatively high temperature (above $c a$. $\left.600^{\circ} \mathrm{C}\right)$, and are small enough $(<c a .5 \mathrm{~nm})$ to be active for the in situ catalytic formation of SWNTs. Characterization of the materials is performed mainly by electron microscopy (SEM, TEM and HREM), ${ }^{57} \mathrm{Fe}$ Mössbauer spectroscopy (MS) and a unique macroscopical technique based on specific-surface-area measurements [5].

\footnotetext{
* Corresponding author.
} 
In this article, some typical aspects of these studies are presented, giving an overview of the results obtained by the present authors. The production of dense composites by hot-pressing the composite powders and the possibility of hydrogen storage in isolated CNTs are suggested as possible applications.

\section{Preparation of the composite powders}

$\mathrm{Mg}_{1-x} \mathrm{Fe}_{x} \mathrm{Al}_{2} \mathrm{O}_{4}(0.1 \leqslant x \leqslant 0.4)[3,6]$ and $\mathrm{Mg}_{0.9} \mathrm{Co}_{0.1} \mathrm{O}$ [4] solid solutions were prepared by the combustion-synthesis route [7]. Briefly, the appropriate amounts of the desired metal nitrates $(\mathrm{Mg}, \mathrm{Al}, \mathrm{Fe}, \mathrm{Co})$ were mixed with urea, dissolved in the minimum amount of water and placed in a furnace pre-heated at $600^{\circ} \mathrm{C}$. Within a couple of minutes, a highly exothermic redox reaction occurred, producing the desired oxide. $\alpha-\mathrm{Al}_{2-2 x} \mathrm{Fe}_{2 x} \mathrm{O}_{3}$ solid solutions were prepared by decomposition in air at $400^{\circ} \mathrm{C}$ and further calcination at $1100^{\circ} \mathrm{C}$ of the corresponding mixed oxalate as described elsewhere [2, 8].

For the synthesis of CNTs-metal-oxide composite powders, a $\mathrm{H}_{2} / \mathrm{CH}_{4}$ mixture (18 mol.\% $\mathrm{CH}_{4}$ ) was used. The flow rate was fixed at $250 \mathrm{~cm}^{3} / \mathrm{min}$. Heating and cooling rates were $5^{\circ} \mathrm{C} / \mathrm{min}$ with a maximum temperature of typically $1000^{\circ} \mathrm{C}$ without dwell.

\section{Electron microscopy}

Figures 1a and c show SEM images of CNTs-Fe- $\mathrm{MgAl}_{2} \mathrm{O}_{4}$ and $\mathrm{CNTs}-\mathrm{Fe}-\mathrm{Al}_{2} \mathrm{O}_{3}$ composite powders, respectively. It appears that the metal-oxide grains are uniformly covered by a web-like network of CNT bundles, several tens of micrometers long. The network seems to be more dense in the specimen with $\mathrm{Al}_{2} \mathrm{O}_{3}$ matrix. The corresponding TEM images (Figures $1 \mathrm{~b}$ and $\mathrm{d}$ ) show that the bundles are made up of SWNTs and small MWNTs (mostly 2-3 walls) with a diameter close to $4 \mathrm{~nm}$. The dark spheres in Figure 1b are metal/carbide catalyst particles.

\section{Mössbauer spectroscopy}

Figure 2a shows the MS spectrum measured at $80 \mathrm{~K}$ of the CNTs-Fe- $\mathrm{MgAl}_{2} \mathrm{O}_{4}$ composite powder obtained by reduction of $\mathrm{Mg}_{0.9} \mathrm{Fe}_{0.1} \mathrm{Al}_{2} \mathrm{O}_{4}$. Three iron phases are detected: a broad sextet characteristic of ferromagnetic $\alpha$-Fe, a narrower one characteristic of ferromagnetic $\mathrm{Fe}_{3} \mathrm{C}$ and a singlet. The corresponding MS parameters are given in Table I. The same specimen measured at $4 \mathrm{~K}$ shows a broadening of the central part of its MS spectrum and was more adequately fitted with a weakhyperfine-field sextet than with a singlet (Figure $2 b$, Table I). This is characterisic of $\gamma$-Fe showing an antiferromagnetic coupling at low temperatures $(<80 \mathrm{~K})$ [9]. It was argued in a previous work [6] that the presence of carbon atoms in the neighborhood of iron explains the stability of these $\gamma$-Fe-C nanoparticles at such low temperatures. 

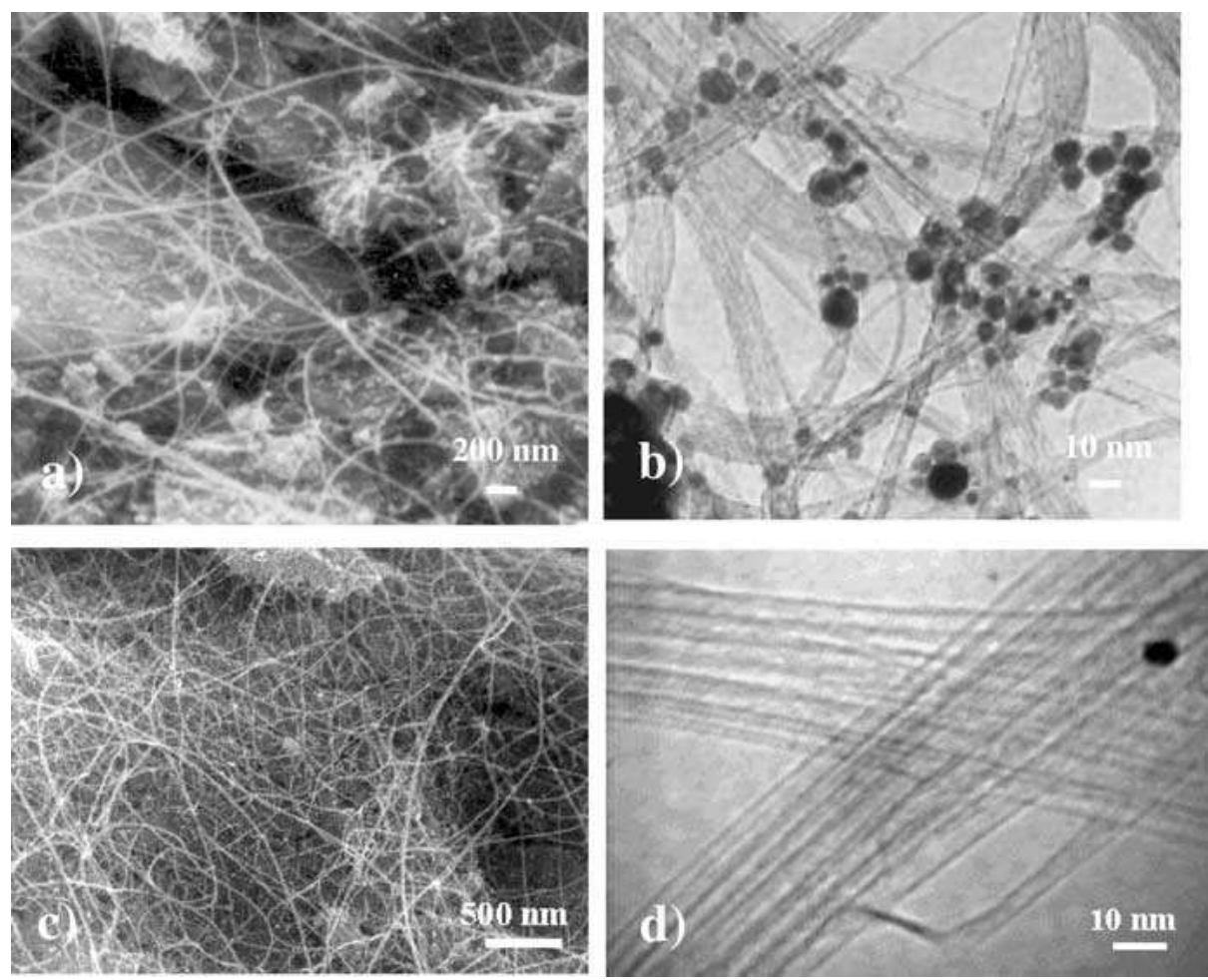

Figure 1. SEM images of CNTs-Fe- $\mathrm{MgAl}_{2} \mathrm{O}_{4}$ (a) and $\mathrm{CNTs}-\mathrm{Fe}-\mathrm{Al}_{2} \mathrm{O}_{3}$ (c) composite powders and the corresponding TEM images ((b) and (d), respectively).

The CNTs- $\mathrm{Fe}-\mathrm{MgAl}_{2} \mathrm{O}_{4}$ composite powders were oxidized in air at $600^{\circ} \mathrm{C}$ which results in the oxidation of all the metal or carbide particles located on the surface of the matrix grains and leaves the intragranular particles unoxidized [10]. By comparing the MS spectra obtained before and after oxidization, it was thus possible to get information about the location of the different iron phases in the composite powder. $\alpha$-Fe and $\gamma-\mathrm{Fe}-\mathrm{C}$ are shown to be dispersed both inside and outside the matrix grains, whereas $\mathrm{Fe}_{3} \mathrm{C}$ is exclusively located outside the matrix grains [10].

Figure 3a shows the evolution of the CNT-quantity parameter $(\Delta S)$ in the $\mathrm{CNTs}-\mathrm{Fe}-\mathrm{MgAl}_{2} \mathrm{O}_{4}$ composite powders in function of the amount of iron ( $x$ in $\mathrm{Mg}_{1-x} \mathrm{Fe}_{x} \mathrm{Al}_{2} \mathrm{O}_{4}$ ) [3,6]. The quantity of CNTs strongly increases between $x=0.1$ and $x=0.2$, reaching saturation for $x \approx 0.3$. The evolution between $x=0.1$ and $x=0.2$ could reflect the higher density of potentially active particles at the surface of the matrix grains upon the increase of the total iron content. For specimens with a higher iron content $(x=0.3$ and $x=0.4)$, this is balanced by an easier coalescence, and hence deactivation, of the surface particles. The proportions of the different iron phases present in the composite powders and determined from the relative spectral areas are shown in Figure 3b. The proportion of $\mathrm{Fe}_{3} \mathrm{C}$ 


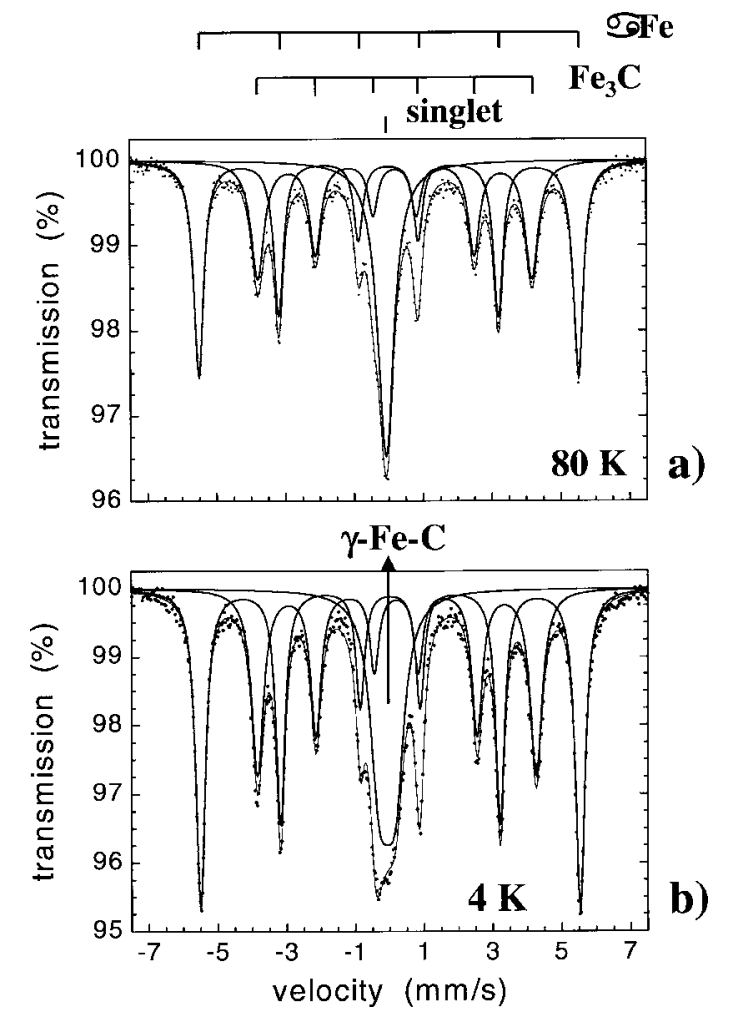

Figure 2. MS spectra measured at $80 \mathrm{~K}$ (a) and at $4 \mathrm{~K}$ (b) of the CNTs-Fe- $-\mathrm{MgAl}_{2} \mathrm{O}_{4}$ composite powder obtained by reduction of $\mathrm{Mg}_{0.9} \mathrm{Fe}_{0.1} \mathrm{Al}_{2} \mathrm{O}_{4}$.

Table I. MS parameters measured at $4 \mathrm{~K}$ and at $80 \mathrm{~K}$ of the $\mathrm{CNTs}-\mathrm{Fe}-\mathrm{MgAl}_{2} \mathrm{O}_{4}$ composite powder obtained by reduction of $\mathrm{Mg}_{0.9} \mathrm{Fe}_{0.1} \mathrm{Al}_{2} \mathrm{O}_{4}$. Ferro: ferromagnetic; antiferro: antiferromagnetic; para: paramagnetic; $H_{\mathrm{hf}}$ : hyperfine field $(\mathrm{kOe}) ; \delta$ : isomer shift $\left(\mathrm{mm} \mathrm{s}^{-1}\right) ; \Delta E_{\mathrm{Q}}$ : quadrupole splitting $\left(\mathrm{mm} \mathrm{s}^{-1}\right) ; 2 \varepsilon_{\mathrm{Q}}$ : quadrupole shift $\left(\mathrm{mm} \mathrm{s}^{-1}\right) ; \Gamma$ : line width $\left(\mathrm{mm} \mathrm{s}^{-1}\right) ; P$ : proportion $(\%)$

\begin{tabular}{|c|c|c|c|c|c|c|c|c|c|c|c|c|c|c|c|}
\hline \multirow{2}{*}{$\begin{array}{c}\mathrm{T} \\
(\mathrm{K})\end{array}$} & \multicolumn{5}{|c|}{ Ferro $\alpha$-Fe } & \multicolumn{5}{|c|}{ Ferro $\mathrm{Fe}_{3} \mathrm{C}$} & \multicolumn{5}{|c|}{ Antiferro/para $\gamma$-Fe-C } \\
\hline & $\delta$ & $H_{\mathrm{hf}}$ & $2 \varepsilon_{\mathrm{Q}}$ & $\Gamma$ & $P$ & $\delta$ & $H_{\mathrm{hf}}$ & $2 \varepsilon_{\mathrm{Q}}$ & $\Gamma$ & $P$ & $\delta$ & $H_{\mathrm{hf}}$ & $2 \varepsilon_{\mathrm{Q}}$ & $\Gamma$ & $P$ \\
\hline 4 & 0.13 & 343 & $0^{*}$ & 0.34 & 45 & 0.31 & 252 & 0.00 & 0.35 & 31.5 & 0.04 & 18.5 & $0^{*}$ & 0.56 & 23.5 \\
\hline 80 & 0.12 & 342 & 0.00 & 0.31 & 44 & 0.30 & 247 & 0.00 & 0.34 & 31.5 & 0.04 & _- & _- & 0.58 & 24.5 \\
\hline
\end{tabular}

*Fixed parameter.

roughly doubles from $c a .30 \%$ to $c a$. $60 \%$ between $x=0.1$ and $x=0.2$ and subsequently reaches saturation. The fraction of $\alpha$-Fe follows an almost opposite evolution, whereas the $\gamma$-Fe-C proportion initially decreases and then increases again in a way that it is similar for $x=0.1$ and $x=0.4$. Figure $3 \mathrm{c}$ shows the evolution of the amounts of the different $\mathrm{Fe}$ phases present in the samples. The contents of both $\mathrm{Fe}_{3} \mathrm{C}$ and $\alpha$-Fe steadily increase with the iron content, the 

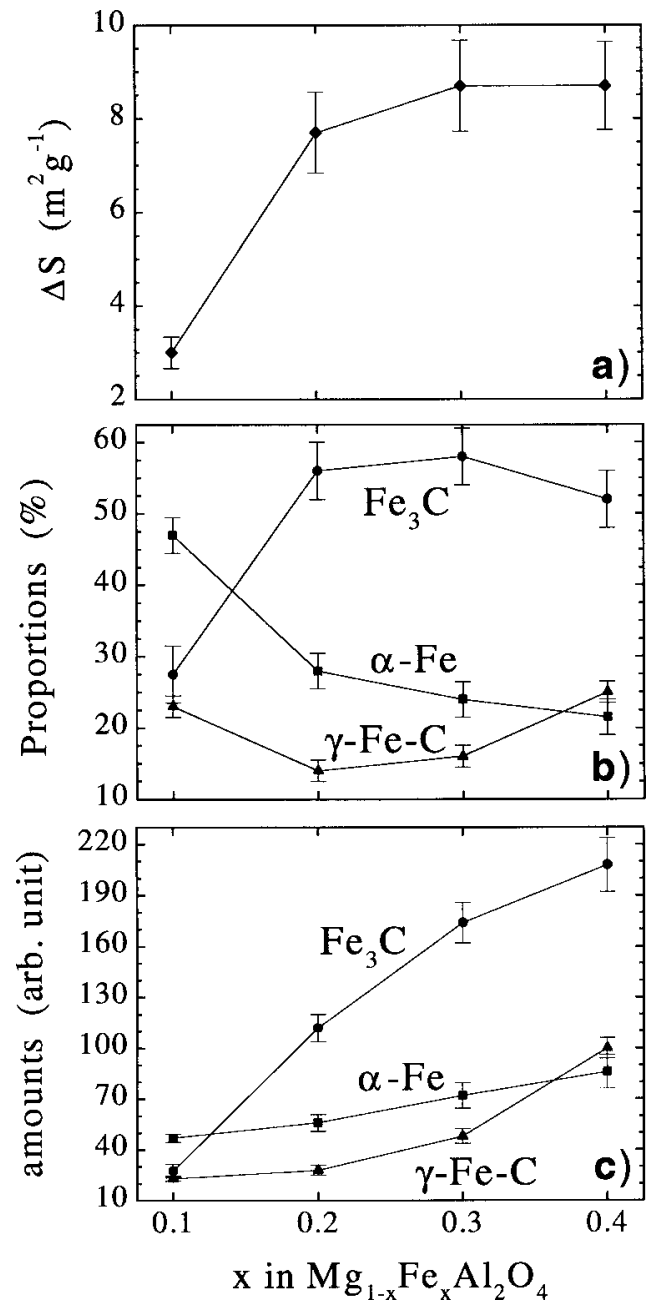

Figure 3. Specific surface areas of carbon in $1 \mathrm{~g}$ of composite powder representing the quantity of CNTs $(\Delta S)$ (a), proportions (b) and amounts (c) of the different iron phases in the CNTs- $\mathrm{Fe}-\mathrm{MgAl}_{2} \mathrm{O}_{4}$ composite powders obtained by reduction of $\mathrm{Mg}_{1-x} \mathrm{Fe}_{x} \mathrm{Al}_{2} \mathrm{O}_{4}$ $(0.1 \leqslant x \leqslant 0.4)$. The lines are guides to the eye.

former one in a much more pronounced way. In contrast, the $\gamma$-Fe-C content is the same for $x=0.1$ and $x=0.2$ and only increases for higher amounts of iron. These results seem to indicate that the particles responsible for the nucleation and possible growth of the CNTs are $\mathrm{Fe}_{3} \mathrm{C}$ by post-reaction MS analyses. The exact nature of the catalytic particle remains so far unknown, but it is probably a very small carbon-containing Fe particle in which some still poorly-established driving forces make carbon atoms to participate in the formation of the CNTs. However, the continuous increase of the $\mathrm{Fe}_{3} \mathrm{C}$ content (Figure 3c) indicates that some of the particles located at the surface of the matrix grains, that were inactive for the 
formation of the CNTs, also end up as cementite. The continuous increase of the quantities of $\alpha$-Fe and $\gamma$-Fe-C further indicates that such inactive particles are $\alpha$-Fe and $\gamma-\mathrm{Fe}-\mathrm{C}$ in post-reaction Mössbauer spectra. The difference in the post-reaction nature of the inactive particles probably reflects the size distribution $(5-20 \mathrm{~nm})$ observed by TEM [3]. The relative thickness of the carbon coating compared to the size of a given particle could influence its post-reaction nature.

\section{Towards applications}

\subsection{HOT-PRESSED COMPOSITES}

The SEM image of Figure 4 shows the fracture surface of a CNTs- $\mathrm{Fe}-\mathrm{Al}_{2} \mathrm{O}_{3}$ dense composite prepared by hot-pressing at $1500^{\circ} \mathrm{C}$ of a CNTs- $\mathrm{Fe}-\mathrm{Al}_{2} \mathrm{O}_{3}$ composite powder. Compared to Figure 1c, the quantity of CNTs has considerably decreased, probably due to the reaction of some CNTs with residual $\mathrm{O}_{2}$ to form gaseous carbon species [11]. It has not been demonstrated so far that the presence of CNTs improves the mechanical characteristics of the composites as expected from theoretical and experimental studies on the individual CNTs themselves. Nevertheless, work is in progress to prepare composites that could benefit from the exceptional characteristics of the CNTs, notably by increasing the CNTs volume fraction, improving the relative density of the composites, enhancing the cohesion between the nanotubes bundles and the matrix and giving a preferential orientation to the bundles. Furthermore, it has been shown that the dense CNTs-metal-oxide materials display an electrical conductivity (of the order of $1 \mathrm{~S} / \mathrm{cm}$ ) due to the percolation of the CNTs network while carbon-free similar composites are insulators [12].

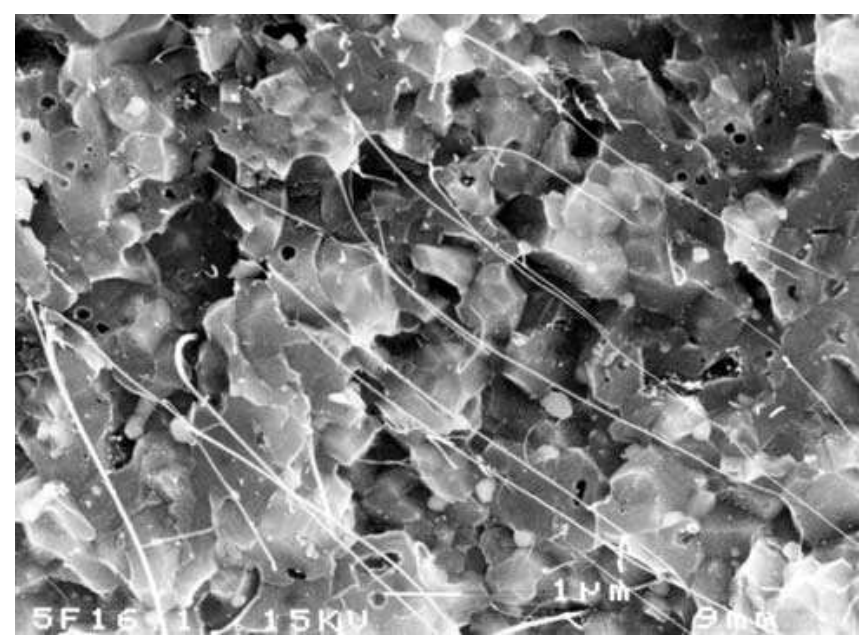

Figure 4. SEM image of a CNTs- $\mathrm{Fe}-\mathrm{Al}_{2} \mathrm{O}_{3}$ dense composite. 


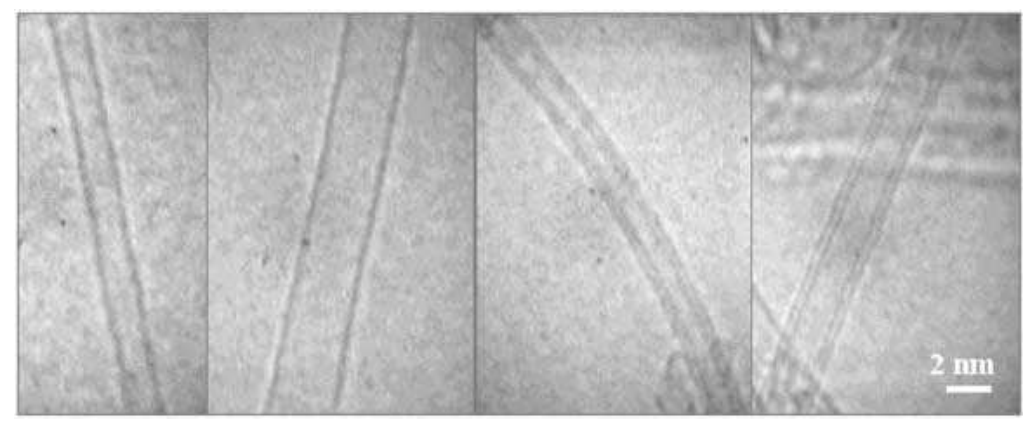

Figure 5. HREM images of extracted CNTs.

\subsection{EXTRACTION OF THE CARBON NANOTUBES}

Using the CNTs-Co-MgO composite powder prepared by reduction of $\mathrm{Mg}_{0.9} \mathrm{Co}_{0.1} \mathrm{O}$, it was possible to extract the CNTs from the $\mathrm{MgO}$ matrix by a mild acid treatment in $\mathrm{HCl}$ [4]. Figure 5 shows HREM images of such extracted CNTs. Measurements of more than $60 \mathrm{CNT}$ s on such images show [4] that $c a .90 \%$ of the CNTs have either 1,2 or 3 walls and a diameter distribution in the range $0.5-5 \mathrm{~nm}$, most of them having a diameter smaller than $3 \mathrm{~nm}$. This indicates the size range of the catalytic particles for SWNTs and thin MWNTs. Larger particles either become onionated or give rise to the formation of larger MWNTs or even hollow carbon fibers.

The storage of hydrogen, particularly for the development of fuel cells, is an important challenge which has been recently focused on the use of CNTs. The first report announcing interesting hydrogen storage capabilities in SWNTs was published in 1997 [13]. A tremendous activity then started with the goal of reaching the value of around 6.5 weight $\%$ of stored hydrogen per system weight in order to obtain economically interesting materials. Several groups reported varying results on different samples utilizing different measuring techniques. However, these results are always achieved by a single group and never reproduced by other researchers. Indeed, if the tubular geometry appears ideal for gas storage, various processes have to be improved, including purification, degassing and opening of the tubes. Recently, we have reported [14] the synthesis of CNTs samples with a very high specific surface area ( $c a .950 \mathrm{~m}^{2} / \mathrm{g}$ of carbon), which may be desirable for increasing the storage capacity.

\section{Conclusions}

$\mathrm{Mg}_{1-x} \mathrm{Fe}_{x} \mathrm{Al}_{2} \mathrm{O}_{4}(x=0.1,0.2,0.3,0.4), \mathrm{Mg}_{0.9} \mathrm{Co}_{0.1} \mathrm{O}$ and $\mathrm{Al}_{2-2 x} \mathrm{Fe}_{2 x} \mathrm{O}_{3}$ solid solutions were transformed into CNTs-Fe- $\mathrm{MgAl}_{2} \mathrm{O}_{4}, \mathrm{CNTs}-\mathrm{Co}-\mathrm{MgO}$ and CNTs$\mathrm{Fe}-\mathrm{Al}_{2} \mathrm{O}_{3}$ composite powders by reduction in a $\mathrm{H}_{2} / \mathrm{CH}_{4}$ gas mixture. Different iron phases have been detected in the composite powders by MS: ferromagnetic $\alpha$-Fe, ferromagnetic $\mathrm{Fe}_{3} \mathrm{C}$ and paramagnetic/antiferromagnetic $\gamma$-Fe-C. It has been 
attempted to correlate these results with the microstructure of the powder. This study suggests notably that the particles that catalyze the formation of the CNTs are $\mathrm{Fe}_{3} \mathrm{C}$ in post-reaction examination.

Two kinds of possible applications have been suggested: massive composites obtained by hot-pressing of the composite powders and hydrogen storage in extracted CNTs. In general, it appears that the recent development of various synthesis methods to produce reasonable amounts of CNTs has increased the possibility of their use for technological applications, large-scale industrial techniques, to obtain kilograms or tons of well-characterized product, are still to be developed.

\section{Acknowledgements}

The authors would like to thank Mr. L. Datas for his assistance in the TEM and HREM observations, which have been performed at the Service Commun de Microscopie Electronique à Transmission, Université Paul-Sabatier. This research is supported by the Belgian National Programme of Inter-University Attraction Pole on Reduced Dimensionality Systems (P4/10), by the Fund for Scientific Research, Flanders and by the Franco-Belgian TOURNESOL programme (T99/006-T99/045).

\section{References}

1. Iijima, S., Nature 354 (1991), 56.

2. Peigney, A., Laurent, Ch., Dobigeon, F. and Rousset, A., J. Mater. Res. 12 (1997), 613.

3. Flahaut, E., Govindaraj, A., Peigney, A., Laurent, Ch., Rousset, A. and Rao, C. N. R., Chem. Phys. Lett. 300 (1999), 236.

4. Flahaut, E., Peigney, A., Laurent, Ch. and Rousset, A., J. Mater. Chem. 10 (2000), 249.

5. Peigney, A., Laurent, Ch., Flahaut, E., Bacsa, R. R. and Rousset, A., Carbon 39 (2001), 507.

6. Coquay, P., De Grave, E., Vandenberghe, R. E., Dauwe, C., Flahaut, E., Laurent, Ch., Peigney, A. and Rousset, A., Acta Mater. 48 (2000), 3015.

7. Kingsley, J. J. and Patil, K. C., Mater. Lett. 6 (1988), 427.

8. Devaux, X., Laurent, Ch. and Rousset, A., NanoStruct. Mater. 2 (1993), 339.

9. Weiss, R. J., Proc. Phys. Soc. 82 (1963), 281.

10. Coquay, P., Laurent, Ch., Peigney, A., Quénard, O., De Grave, E. and Vandenberghe, R. E., Hyp. Interact. 130 (2000), 275.

11. Laurent, Ch., Peigney, A., Dumortier, O. and Rousset, A., J. Eur. Ceram. Soc. 18 (1998), 2005.

12. Flahaut, E., Peigney, A., Laurent, Ch., Marlière, Ch., Chastel, F. and Rousset, A., Acta Mater. 48 (2000), 3803.

13. Dillon, A. C., Jones, K. M., Bekkadahl, T. A., Kiang, C. H., Bethune, D. S. and Heben, M. J., Nature 386 (1997), 377.

14. Bacsa, R. R., Laurent, Ch., Peigney, A., Bacsa, W. S., Vaugien, Th. and Rousset, A., Chem. Phys. Lett. 323 (2000), 566. 